\title{
Sovereignty and the Politics of Property
}

\author{
Eyal Benvenisti*
}

\begin{abstract}
The debate whether property is a limit on or the product of sovereignty envisages a tension between "the individual owner" and "the state." But "the state" is not more than the aggregate of individuals who define theirs and others' property rights through the state's political process. The underlying tension between property and sovereignty is thus the tension between the economic market and the political market. Owners and others compete simultaneously at both levels to define, protect or improve the value of property. There are two ways to compete in the political marketplace: by engaging either in "high visibility politics" or in "low visibility politics." Diffuse owners rely on "high visibility politics" promoted by agents such as political parties or trade unions and on elections, referenda and the like, whereas smaller groups of owners prefer the "low politics" of capturing lawmakers and state executives.

When economic markets became global at the end of the Cold War, so did the political markets: property rights increasingly became defined by international agreements, by decisions of international organizations, and by the exercise of "low politics" in foreign, weaker states. The global political markets were dominated by the executive branches of a handful of relatively strong states that, in turn, were responsive to the "low politics" of special interests. The high transaction costs of cooperation among diffuse owners inhibited the parallel rise of "high politics" at the global level. The skewed global political market for property continues to favor special interests, but there are budding attempts to reclaim the space for "high politics" by national regulators and courts. Current negotiations over the so-called "Mega Regional" agreements between the U.S. and its trading partners will, if successful, nip these buds as they render certain property rights almost immune to the subsequent challenges of high politics.
\end{abstract}

\footnotetext{
* Whewell Professor of International Law, University of Cambridge, Law Professor, Tel Aviv University, Global Professor, NYU School of Law. I thank Hanoch Dagan, Tsilly Dagan, Roy Kreitner for their valuable comments and Etya Rottman-Frand for her careful research assistance. Research for this Article was supported by the European Research Council Advanced Grant (grant agreement (grant No. 323323).
} 


\section{Introduction}

The debate whether property is a limit on or the product of sovereignty envisages a tension between "the individual owner" and "the state." But "the state" is not more than the aggregate of individuals who define theirs and others' property rights through the political process. Stated differently, then, the underlying tension between property and sovereignty is a tension between the citizens. The citizens operate to define and redefine their property rights through the economic market and the "political market." The economic market is the arena where owners define their rights through unilateral action or consensual transactions. The political market is the venue where voters and organized interests compete over control of the state's lawmaking and regulatory functions. While traditionally the political market was domestic, defined by national laws and institutions, it increasingly opens up to various supra- and international arenas where entitlements are shaped by formal and informal international public or private agreements. Owners compete simultaneously in both economic and political arenas to define, protect and improve the value of their property.

In principle, there are two ways for owners to compete in the political marketplace: they can engage in what we could call, as perhaps a useful heuristic, either "high visibility politics" or "low visibility politics (or any combination thereof). Diffuse owners (and, of course, those who own nothing), for whom collective action through the economic market is impossible or costly, rely instead on agents such as political parties or trade unions that are active in "high visibility politics" ("high politics"), ${ }^{1}$ which includes elections and referenda, strikes, demonstrations and, ultimately, revolutions. They obtain their information from high visibility media informed by investigative journalism and leaks. These political agents transform demands for the definition of property rights (e.g., as collective vs. private), or for the redistribution of property, into political platforms.

At the same time, smaller groups of owners turn their numerical disadvantage into political gain ${ }^{2}$ by forming lobbies that pursue "low (visibility) politics" of capturing and otherwise cultivating lawmakers and state executives, steering them to refrain from intervention in the economic market or to intervene on their behalf in various ways (usually by a complex mix of regulation

\footnotetext{
${ }^{1}$ ANTHONY DOWNS, AN ECONOMIC THEORY OF DEMOCRACY (1957).

${ }^{2}$ Mancur Olson, The Logic of Collective Action (1965).
} 
and deregulation, privatization and "publicization"). They also try to steer media reporting to their side by buying or putting economic pressure on media outlets. Success in low visibility political gains by, for example, capturing state institutions, may prove more valuable than high visibility gains reflected in clear laws that secure entitlements. Indeed, recent evidence in the sphere of foreign investment suggests that foreign investors are attracted to countries where property rights are poorly defined but where the expectations of the investors can be secured by capturing the local government. ${ }^{3}$

A fair equilibrium between (and within) these two types of owners, if achieved, would be reinforced by clear delineation of rights that are secured by institutional checks and balances , such as courts, central banks and other regulators. ${ }^{4}$ Arguably, some developed democracies have managed to reach a relatively fair equilibrium during the second half of the twentieth century, a result of intense competition among interest groups and between them and diffuse voters.

When economic markets became global at the end of the Cold War, so did the political markets: property rights increasingly became defined by international agreements, by decisions of international organizations, by informal government-to-government understandings, by de facto delegation of authority to private initiatives to set standards for markets, and by the exercise of "low politics" in foreign, weaker or stronger states. The global political markets were dominated by the executive branches of a handful of relatively strong, mainly northern states that, in turn, were responsive to the "low politics" of special interests. The high transaction costs of cooperation among diffuse and relatively less endowed owners - now including individuals from many countries - has inhibited the parallel rise of "high politics" at the global level. As a result, the skewed global political market for property favored the special interests, mainly but not exclusively of richer, northern countries.

But in what may have been a surprise to some observers, a few national legislatures and courts continued to serve as venues for "high politics" despite the external pressures. The 2013

\footnotetext{
${ }^{3}$ See below.

${ }^{4}$ For an analysis of the evolution of a political system that protects property rights to curb the British King's discretion and ensure stability of expectations see Douglass C. North and Barry R. Weingast, Constitutions and Commitment: The Evolution of Institutions Governing Public Choice in Seventeenth-Century England, 49 J. EcoN. HIST. 803 (1989). For an explanation of the success of the economies of certain East Asian countries as grounded in stable expectations of owners large and small see JOSE E. CAMPOS \& HiLton L. RoOT, THE Key to the Asian Miracle: MAKING Shared Growth CREDIBLE (1996).
} 
judgment of the Supreme Court of India in Novartis v. India, ${ }^{5}$ which interpreted narrowly the TRIPS agreement's scope of IP protection, exhibited the potential for offsetting the clout of the big multinationals by using state institutions. ${ }^{6}$ The European Parliament's fateful refusal to ratify the Anti-Counterfeiting Trade Agreement ${ }^{7}$ in 2012 following mass protests against that measure demonstrated the promise of the resurrection of "high politics" at the global level.

However, the Novartis judgment and the European Parliament's vote also served as triggers for redoubled efforts to expand the global space of "low politics." The ongoing secret negotiations over the so-called "Mega Regional" agreements between the U.S. and its trading partners are set to redefine certain property rights and render them almost immune to the subsequent challenges of high politics. Such a victory for "low politics" may be not only unjust but also short-sighted. Instead, a stable global equilibrium between the two competing camps, reinforced by robust domestic and global checks and balances, is not only morally required but also in the long-term interest of both camps.

The aim of this essay is to provide an overview of the intimate interaction between the two markets for property as they play out in the global arena. The story is obviously evolving, and attention must be paid to the potential impact of the "Mega Regional" agreements and the possible reactions to them. A full analysis of "winners" and "losers" as well as a normative assessment of the current property regimes is beyond the scope of this essay, although I will hint at certain aspects of efficiency and equity that arise and at possible institutional remedies. Part II provides a general overview of the processes by which voters and interest groups compete in the political marketplace to define their respective property rights. Part III analyzes the turn to global political markets and explains the systemic advantage of low politics at the global level. Part IV explores the emerging efforts to create venues for high politics to counter the reign of low politics in global markets, as well as the more recent effort to respond and silence these nascent initiatives. Part V concludes.

\footnotetext{
5 Novartis AG v. Union of India \& Others, A.I.R 2013 S.C. 1311 (India) (available at http://judis.nic.in/supremecourt/imgs1.aspx?filename=40212).

${ }^{6}$ See below.

${ }^{7}$ Margot E. Kaminski, An Overview and the Evolution of the Anti-Counterfeiting Trade Agreement, 21 ALB. L.J. SCI. \& TECH. 385 (2011).
} 


\section{The Globalization of the Political Markets for Property}

(a) Overview

The struggle for the definition of property rights takes place simultaneously in the economic and the political marketplaces. Saul Levmore has pointed out that the definition of property rights may result from specific distributions of transaction costs (what I term here the economic market) or from interest-group influence (the political market). ${ }^{8}$ Usually, the process of definition will not be a story of "either-or," as both the economic and the political markets would have a simultaneous or sequential effect on the right. The economic markets reflect scarcity and transaction costs and these shape the capabilities and incentives of individuals and groups to assert rules that exclude nonusers and overcome challenges of resource management - think about the farmers in Shasta County, the "Robber Barons" who appropriated the Rhine, or Google and other Big Data storage corporations who regard the data they store as exclusively theirs. ${ }^{9}$ These rules - efficient, egalitarian, or neither - may or may not be reflected - bottom-up - in formal state law. ${ }^{10}$ At the same time property rights are also shaped top-down by the political process. ${ }^{11}$ The political market will not be influenced only by interest groups, as voting rules also tend to have a significant impact on outcomes, ${ }^{12}$ and - to the extent that one is willing to concede that sometimes deliberations are effective - diffuse voters might also have a say in the definition of rights.

As suggested above, there are two ways for owners to compete in the political marketplace for defining their property rights: they can engage in "high visibility politics" or in "low visibility

\footnotetext{
${ }^{8}$ Saul Levmore, Two Stories About the Evolution of Property Rights, 31 J. Legal Stud. S421 (2002); See also Daniel Fitzpatrick, Evolution and Chaos in Property Rights Systems: The Third World Tragedy of Contested Access, 115 YALE L.J. 996 (2006); Stuart Banner, Transitions between Property Regimes, 31 J. LEGAL STUD. S359 (2002).

${ }^{9}$ Henry E. Smith, Exclusion Versus Governance: Two Strategies for Delineating Property Rights, 31 J. LEGAL STUD. S453 (2002); Harold Demsetz, Toward a Theory of Property Rights, 57 AM. ECON. REV. PAPERS \& PROC. 347 (1967); Ronald H. Coase, The Problem of Social Cost, 3 J.L. \& ECon. 1 (1960); Louis L. Jaffe, Law Making by Private Groups, 51 Harv. L. Rev. 212 (1937); Omri Yadlin, A Public Choice Approach to Private Ordering, 98 Mich. L. ReV. 2620 (2000). See also Gregory S. AleXAnder \& Hanoch Dagan, Properties of Property (2012) (at chapter 11).

${ }^{10}$ Robert C. Ellickson, Order Without Law: How Neighbors Settle Disputes (1991); Elinor Ostrom, GOVERNING THE COMMONS: THE EVOLUTION OF INSTITUTES FOR COLleCtIVE ACTION (1990).

${ }^{11}$ Katrina Miriam Wyman, From Fur to Fish: Reconsidering the Evolution of Private Property, 80(1) N.Y.U. L. Rev. 117 (2006); See also ItAi Sened, The Political Institutions of Private Property 76 (1997).

${ }^{12}$ Wyman, supra note 11.
} 
politics" (or any combination thereof). Diffuse owners, for whom collective action through the economic market is costly, rely instead on agents such as political parties or trade unions that are active in "high politics": elections and referenda, strikes, demonstrations and, ultimately, revolutions. ${ }^{13}$ Smaller groups of owners, for whom cooperation is feasible, prefer high politics only if capture is not an available option or if it is an option they all commit to shun. For example, instead of futile attempts to influence an unresponsive king, competitors would insist on delimiting the king's discretion, as the wealthy Englishmen have done after the Glorious Revolution. ${ }^{14}$ But otherwise, smaller groups would tend to pursue the "low politics" of capturing lawmakers and state executives. Small groups may also try to shape public opinion by supporting candidates' campaigns or by buying influence in media outlets, ${ }^{15}$ but this "high politics" intervention (always indirect and unacknowledged) will be used to help their agents get the votes they need for reelection, not to influence the choice made by these agents. ${ }^{16}$

Often private ownership provides not only the incentive but also the ability to overcome collective action costs and form interest groups. George Stigler has exposed the ways the interest group of railroad companies used state authority to preempt competition from truck drivers. ${ }^{17}$ What Carl Reich optimistically called "New Property"18 was exposed by Stigler as a means of intervening in the "Old Property" market by enclosing commons, creating entry barriers, etc. Mancur Olson's theory of collective action ${ }^{19}$ provided the explanation why Stigler's findings could be generalized: smaller groups are more likely to succeed through "low politics" to shape public policies at the expense of the larger groups with their "high politics" methods. Olson explained and Stigler proved that the underlying concern of the U.S. Constitution, that the minority of property owners must be protected from the landless masses, ${ }^{20}$ wasn't real: the use of

\footnotetext{
${ }^{13}$ On informational asymmetries and the consequential reliance on agents such as political leaders, see Downs, supra note 2.

${ }^{14}$ North and Weingast, supra note 5 (discussing the effects of the redesigned political institutions after the Glorious Revolution on the improved security of property rights and the emergence of private capital markets).

${ }^{15}$ Citizens United v. Federal Election Committee, 558 U.S. 310 (2010).

${ }^{16}$ Cf. Stein Rokkan, Norway: Numerical Democracy and Corporate Pluralism, in POLITICAL OPPOSITION IN WESTERN DEMOCRACIES, 70, 106 (Robert Dahl Ed., 1966) ("votes count in the choice of governing personnel, but other resources decide the actual policies pursued by authorities.").

${ }^{17}$ George Stigler, The Theory of Economic Regulation, 1 BELL J. ECON. MGMT. SCI. 3 (1971).

${ }^{18}$ Charles A. Reich, The New Property, 73 Yale L.J. 733 (1964).

${ }^{19}$ Olson, supra note 3.

${ }^{20}$ Landowners were particularly concerned that a landless majority would use its numerical superiority to redistribute property. See THE FEDERALIST No. 10 (James Madison) (discussing property ownership as a basis for conflict of interests among voters and legislators). The installation of a complex and diversified system of
} 
"high politics" to limit the small group of property owners is an inherently limited strategy because political agents are susceptible to the property owners' capture efforts.

As Mancur Olson elaborates in The Rise and Decline of Nations, ${ }^{21}$ because smaller groups could organize themselves more quickly than their opponents within the nascent Westphalian system of sovereign states, they were able to use the state as the instrument for obtaining a disproportionate share of the domestic resources. But in robust democracies, rival political parties exert constant pressure to level the political playing field and check the influence of special interests. If successful, a fair equilibrium between these two camps of owners, as well as an equilibrium within the two camps (e.g., between the city and the countryside, between truck and railroad companies $^{22}$ or between importers and exporters), will be achieved. This equilibrium will be reinforced by state institutions that provide for robust checks on voters and bureaucrats, such as courts, central banks and other regulators, and by norms that on the one hand define property rights in a relatively clear manner ${ }^{23}$ and impose effective limits on takings, and on the other hand provide for transparency and participation in public decision-making and otherwise subject the discretion of public authorities to judicial review. ${ }^{24}$ The battle of high politics vs. low politics will then focus on the extent to which such regulators are insulated from the influence of low politics.

Obviously, if sufficiently independent, courts, central bankers and other regulators could become themselves effective players in the political-legal struggle to shape property rights. Removed from the often skewed political battle, these regulators are quite likely to reach outcomes that are

government, supermajority amendment requirements, and judicial review to protect constitutional rights such as the right to property responded to such concerns. See id.; THE FeDERALIST No. 51 (Alexander Hamilton or James Madison) (discussing the political structures for curbing such conflict of interests).

${ }^{21}$ MANCuR Olson, THE Rise AND DeCline OF NATIONS Chapter 3 (1982).

${ }^{22}$ Stigler, supra note 18.

${ }^{23}$ On the link between the clear definition of property rights and protection of poor owners against "land grabs," see Rabah Arezki, Klaus Deininger \& Harris Selod, What drives the global land rush? (IMF Working Paper Working Paper No. 11/251, 2011), available at http://www.cepii.fr/institutions/doc/2011_Arezki_et_al.pdf.

${ }^{24}$ See William M. Landes \& Richard A. Posner, The Independent Judiciary in an Interest-Group Perspective, 18 J.L. \& ECON. 875 (1975) (presenting constitutional guarantees as securing legislative deals among diverse interest groups); See Donald J. Boudreaux \& A. C. Pritchard, Reassessing the Role of the Independent Judiciary in Enforcing Interest-Group Bargains, 5 CONST. POL, ECON. 1 (1994). 
both fair and efficient, or at least ensure sincere and inclusive public deliberation that can lead to such outcomes. ${ }^{25}$

(b) The Political Market Goes Global

As much as the smaller groups used the state as an instrument for obtaining a disproportionate share of the domestic resources, they also embraced the state as a tool for expanding their wealth in foreign markets. The state apparatus has offered cover for entrepreneurs operating beyond state borders. The widely accepted constitutional doctrine, that the state executive has the sole authority to engage in international relations, was a boon to small groups whose success was tied to "low politics" because of the relative opaqueness of executive action and the dearth of effective checks on "foreign affairs" compared to legislation. By influencing the global activities of their or other states' executives, special interests could shape the political markets of many if not most states.

One arena traditionally used by small groups seeking to define property rights has been international law and its typical tools - treaties and decisions of international institutions. In fact, the very first international organization was set up in 1804 to demolish the property rights of the Robber Barons over navigation on the Rhine, ${ }^{26}$ and one of the first instances of a prohibition derived from international law was the abolition of the slave trade which resulted from a British policy motivated by a combination of "high politics" and the decreasing benefits of this trade to

${ }^{25}$ Hanoch Dagan, Judges and Property, in InTellectual Property AND the COMmon Law 17, 35-39 (Shyamkrishna Balganesh ed., 2015) (emphasizing adjudication as enjoying, at times, "a significant comparative advantage" in defining property rights. At p.39 Dagan writes: "If most or many property matters are either politically marginal or dominated by interest groups, the legislators' expected responsiveness is likely to be rather limited."). For the opposite view, see Avihay Dorfman, Property and Collective Undertaking: The Principle of Numerus Clausus, 61 U. TORONTO L.J. 467, 510-13 (2011)).

${ }^{26}$ The treaty instituted a single toll levied by a joint administration controlled by the French government and by the arch-chancellor of the German Empire. This first IGO had the responsibility to use the proceeds of the toll to improve navigability and the state of the towpaths, as well as to settle disputes with the various cities and princes along the river for having lost their right to impose levies. Dale S. Collinson, The Rhine Regime in Transition Relations between the European communities and the Central Commission for Rhine Navigation, 72 COLUM. L. Rev. 485 (1972); Joseph Perkins Chamberlain, The Regime of the InTERnational Rivers: Danube and RHINE 147-87 (1923). For excerpts of the text see http://www.ccr-zkr.org/files/histoireCCNR/02_annexe-16-b-du24-mars-1815.pdf. 
British commerce. $^{27}$ It is not surprising that international law itself (the way it is made and interpreted), shaped primarily by state executives, has come to reflect and enhance the "low politics" of special interests who use it to gain ground in national regulatory processes. As I have argued elsewhere, "Smaller groups have been successful in influencing international negotiations and international law since the very inception of the Westphalian order of sovereign states."28 Treaties are negotiated by state executives and the other political branches have only limited means and insufficient information to intervene. Once ratified, the treaties bind future generations of voters without the ability to unilaterally terminate the treaty. The interpretation of the treaty is usually a matter for the executive, and escape clauses in the treaty text ensure convenient exit options for interest groups. ${ }^{29}$

International law has always reflected the interests of the developed world, in particular in the context of protecting the property of foreign owners. It is international law that is responsible for the invention of the corporation that on the one hand is independent of its foreign parent company, ${ }^{30}$ but at the same time is recognized as owned by the foreign company and hence immune from taking by the state of incorporation (or otherwise whose expropriation entitles the owner to prompt, adequate and effective compensation). ${ }^{31}$ Moreover, if operated from a third country, the tax laws of both host state and the parent's company's home state will not apply, and the entire operation could thus benefit from "tax havens." This ingenious legal invention perhaps no less momentous for global business than the very invention of the company. The obligation to accord foreign investments "fair and equitable treatment" has become a keyword for imposing an increasingly demanding set of standards on host states by privatized dispute resolution mechanisms that were set up to insulate foreign investors from the national courts of

\footnotetext{
${ }^{27}$ On the high politics in Britain at the time, see ADAM HochsCHILD, BURY THE CHAINS: THE BRITISH STRUGGLE TO AbOlish SlaVery (2005); on the use of international law to enforce the ban, see JenNy S. MARTinez, The SLAVE TRADE AND THE ORIGINS OF INTERNATIONAL HUMAN RigHTS LAW (2012).

${ }^{28}$ Eyal Benvenisti, Exit and Voice in the Age of Globalization, 98 Mich. L. REv. 167 (1999).

${ }^{29}$ GeORGE W. DOWNS \& DAVID M. Rocke, OPTIMAL IMPERFECTION? (1995).

${ }^{30}$ See Ronen Palan "Tax Havens and the Commercialization of State Sovereignty" 56 International Organization, 151, 168-169 (2002).

${ }^{31}$ This wording (in relation to lawful expropriation) is known as the "Hull formula," named after the American Secretary of State who declared in 1938 that Mexico is obligated to pay compensation for expropriation for any reason whatsoever: "[U]nder every rule of law and equity, no government is entitled to expropriate private property, for whatever purpose without provision for prompt, adequate and effective payment therefor." GREEN HAYEOOD HACKWORTH, DigEST OF INTERNATIONAL LAW 657 (1943).
} 
the host states. ${ }^{32}$ The efforts of developing countries to transform talking shops such as the General Assembly of the United Nations into "high politics" fora, in order to press for a shift in foreign property protection by promoting a so-called "New International Economic Order," failed miserably and ended once the Soviet bloc disintegrated. ${ }^{33}$

When economic markets became global at the end of the Cold War, property rights increasingly became defined by international agreements and by decisions of international organizations. International law has become a tool to discipline the majority of states to conform to global standards on various aspects of property definition and use (e.g., pollution and use of natural resources, IP rights). Perhaps because the traditional tools of international law have become too public for some, and hence subject to the muster of "high politics" or parliamentary ratification, governments of powerful states have begun to turn to informal cooperation through "networks" of state executives, or to de facto delegation of standard-setting functions to private actors. ${ }^{34}$ The global political markets of today are dominated by the executive branches of a small subset of relatively strong states that, in turn, have been responsive to the "low politics" of special interests and opaque to "high politics." And no surprise, the standards set by these informal networks reflect the interests of the powerful states. ${ }^{35}$

One example of the success of small groups in the global political arena is the struggle to define the global protection of IP rights. Margot Kaminski is among the scholars who have been monitoring the ways in which the U.S. has "aggressively shifted among various international law and policy-making forums to promote a goal of harmonizing the world's intellectual property laws in its image." 36 The effort began with the creation of the World Trade Organization (WTO) in 1995. The WTO consisted of the old GATT regime and the new General Agreement on Trade

32 Julie A. Maupin, Public and Private in International Investment Law: an Integrated Systems Approach, 54(2) VIRGINIA J. INT'L L. 367 (2014); Lise Johnson \& Oleksandr Volkov, Investor-State Contracts, Home-State "Commitments" and the Myth of Stability in International Law, 24(3) AM. REV. INT'L ARB. 361 (2013); Robert Stumberg, Sovereignty by Subtraction: The Multilateral Agreement on Investment, 31 CORNELL INT'L L.J 491 (1998); Andreas F. Lowenfeld, Investment Agreements and International Law, 42 COLUM. J. TRANSNAT'L L. 123 (2003).

${ }^{33}$ Stumberg \& Lowenfeld, supra note \# ; Doreen Lustig's paper (forthcoming 2016).

${ }^{34}$ Eyal Benvenisti, The Law of Global Governance, Chapter 2 (2014).

${ }^{35}$ For example, in antitrust policies see Eleanor Fox, Antitrust Without Borders: From Roots to Codes to Networks, in COOPERATION, COMity AND Competition Policy (Andrew T. Guzman ed.,2010), Tristan Feunteun, Cartels and the Right to Food: An Analysis of States' Duties and Options, 18 J. InT'L Econ. L. 341, 368 (2015).

${ }^{36}$ Sean M. Flynn, Brook Baker, Margot Kaminski, and Jimmy Koo, The U.S. Proposal for an Intellectual Property Chapter in the Trans-Pacific Partnership Agreement, 28 AM. U. INT'L L. REV. 105 (2012). 
in Services, and the Trade-Related Aspects of Intellectual Property Rights (TRIPS). The commitment to protect IP rights globally was imposed by the U.S. and the EU by making the future of trade liberalization conditional on that. ${ }^{37}$ But legislatures and courts in the developing world have interpreted their obligations narrowly, ${ }^{38}$ and IP owners sought to enhance their rights even further. As multilateral negotiations over updating the WTO accords failed, the U.S. moved to bilateral free trade area (FTA) agreements, to an Anti-Counterfeiting Trade Agreement (which was defeated by the EU Parliament that refused to ratify it), ${ }^{39}$ and most recently to secretive negotiations over "Mega-Regional" agreements with the EU and with several Pacific Rim countries. ${ }^{40}$ If these negotiations succeed they will set new global standards for IP protection that will have significant negative ramifications for the access to drugs. ${ }^{41}$

Another strategy of certain actors has been to evade the global political markets altogether, or rather to have the sovereigns delegate regulatory functions to private actors or endorse practical immunity for markets through deregulation and privatization. Multinational corporations (MNCs) break up the production chain into different links that occur in different localities, taking advantage of the free movement of capital and operations; thus, they can not only benefit from different standards of production, but also shape those standards and impose them on host governments vying for foreign money. ${ }^{42}$

Furthermore, interest groups have begun to directly exercise "low politics" in foreign, weaker states. $^{43}$ Their influence is felt in key areas such as international taxation (e.g., bilateral tax

\footnotetext{
${ }^{37}$ Richard H. Steinberg, Judicial Lawmaking at the WTO: Discursive, Constitutional, and Political Constraints, 98 AM. J. INT'L L. 247 (2004); Richard H. Steinberg, In the Shadow of Law or Power? Consensus-Based Bargaining and Outcomes in the GATT/WTO, 56 INT'L ORG. 339 (2002); Eyal Benvenisti \& George W. Downs, The Empire's New Clothes: Political Economy and the Fragmentation of International Law, 60 STAN. L. REV. 595 (2007).

${ }^{38}$ See the Indian Supreme Court judgment in Novartis v. The State of India, supra note 6.

${ }^{39}$ Kaminski, supra note 8. .

${ }^{40}$ Christopher Ingraham \& Howard Schneider, Industry Voices Dominate the Trade Advisory System, WASHINGTON PosT, Feb. 27, 2014, http://www.washingtonpost.com/wp-srv/special/business/trade-advisory-committees/.

${ }^{41}$ Eyal Benvenisti, Democracy Captured: The Mega-Regional Agreements 23 CONSTELLATIONS 58 (2016).

${ }^{42}$ For an overview of these developments, see Dan Danielsen, How Corporations Govern: Taking Corporate Power Seriously in Transnational Regulation and Governance, 46 HARV. INT'L L. J. 411 (2005); Gerald F. Davis, Marina V.N. Whitman \& Mayer Nathan Zald, The Responsibility Paradox: Multinational Firms and Global Corporate Social Responsibility (Ross Sch. of Bus. Working Paper Series, Working Paper No. 1031, Apr. 2006). For a critical discussion, see Doreen Lustig \& Eyal Benvenisti, The Multinational Corporation as "the Good Despot": The Democratic Costs of Privatization in Global Settings, 15 THEORETICAL INQUIRIES L. 125 (2014).

${ }^{43}$ Recently: Stavros Gadinis, Three Pathways to Global Standards: Private, Regulator, and Ministry Networks, 109 AM, J. INT'L L. 1 (2015).
} 
treaties that ensure that the host states do not tax the foreign investors), ${ }^{44}$ foreign investment law (and specifically, bilateral investment treaties that secure foreign investment from host state control), ${ }^{45}$ and most recently in the so-called "land-grabbing" phenomenon, the long-term lease of vast tracts of land for cultivation. ${ }^{46}$ For the latter they have sought out states with a poor definition of property rights and weak land governance systems as their choice for investment. ${ }^{47}$ While this comes as a surprise to economists who assumed that stronger property rights regimes would attract investors, ${ }^{48}$ the foreign investors apparently rely on their domination of the political market as the framework for protecting their investments.

Finally, the contemporary global legal arena is also conspicuous for the areas that remain intentionally unregulated. For instance, there are still no effective global regimes - formal or informal - that can overcome global tax competition and tax havens, ${ }^{49}$ to assign state responsibility for acts or omissions of locally registered corporations that operate beyond the national jurisdiction, ${ }^{50}$ or to resolve sovereign defaults in ways that provide equitable burden sharing between borrowers and lenders. ${ }^{51}$

\footnotetext{
${ }^{44}$ Tsilly Dagan, The Tax Treaties Myth, 32(4) N.Y.U. J. InT'L L. \& PoL. 939 (2000); Kim Brooks \& Richard Krever, The Troubling Role of Tax Treaties, 51 TAX DESIGN IsSUES WORLDWIDE, SERIES ON INTERNATIONAL TAXATION 159 (Geerten M. M. Michielse \& Victor Thuronyi, eds., 2015), available at http://papers.ssrn.com/sol3/papers.cfm?abstract_id=2639064 (high-income countries gain from tax treaties with low-income countries because they restrict low-income countries' abilities to collect revenue from income earned in their jurisdictions. For multinational corporations the system offers a simple path to avoid taxation).

${ }^{45}$ Soumyajit Mazumder, Can I Stay a BIT Longer? The Effect of Bilateral Investment Treaties on Political Survival, 10(3) REV. INT'L ORG. 1 (2015) (available at http://shommazumder.github.io/files/BIT-Survival.pdf).

${ }^{46}$ Jochen von Bernstorff, the Global 'Land-Grab', Sovereignty and Human Rights, 2(9) EUROPEAN SOC'Y OF INT'L L. REFLECTIONS (2013), available at http://www.esil-sedi.eu/sites/default/files/ESIL\%20Reflections\%20$\% 20$ von\%20Bernstorff_0.pdf.

${ }^{47}$ Olivier De Schutter, How Not to Think of Land-Grabbing: Three Critiques of Large-Scale Investments in Farmland, 38 J. Peasant Studies 249, 266 (2011); Amnon Lehavi, Land Law in the Age of Globalization and Land Grabbing, in RESEARCH HANDBOOK ON COMPARATIVE PROPERTY LAW (Michele Graziadei \& Lionel Smith eds., forthcoming 2015)(available at http://ssrn.com/abstract=2545844 at p. 25).

${ }^{48}$ Arezki, Deininger \& Selod, supra note 24 at p.17-18 ("In contrast to the literature on foreign investment in general, the quality of the business climate is insignificant whereas weak land governance and tenure security for current users make countries more attractive for investors.").

49 Tsilly Dagan, Community Obligations in International Taxation (forthcoming 2016); REUVEN AVI-YONAH, INTERNATIONAL TAX AS INTERNATIONAL LAW: AN ANALYSIS OF THE INTERNATIONAL TAX REGIME (2007).

${ }^{50}$ See e.g. the Guiding Principles on Business and Human Rights (the "Ruggie Principles").Kiobel v. Royal Dutch Petroleum 569 U.S. _ (2013), Docket No 10-1491.

${ }^{51}$ Joseph E. Stiglitz \& Martin Guzman, The Rule of Law for Sovereign Debt, ProJECT SYNDICATE (June 15, 2015), https://www.project-syndicate.org/commentary/sovereign-debt-restructuring-by-joseph-e-stiglitz-and-martinguzman-2015-06?barrier=true; MiCHAEL WAIBEL, SOVEREIGN DEFAULTS BEFORE INTERNATIONAL COURTS AND TRIBUNALS 163 (2011).
} 


\section{Analysis: The Systemic Advantage of Low Politics at the Global Level}

Why are smaller groups able to exploit the global political markets through low politics even more than the domestic market? The answer in short is that the inherent collective action problems of consolidating political power have become increasingly more challenging for diffuse groups to resolve, while at the same time small groups found it increasingly profitable to overcome their impediments to cooperation. The process of globalization, which increases the dependency of most states on a small set of foreign actors, gives us at least four reasons to worry about the deterioration of the effectiveness of "high politics" by which citizens can exercise agency and control their political branches (beyond the traditional worries about the internal systemic problems of democracy).

First, the continuous lowering of the technical and legal barriers to the free movement of people, goods, services, and capital across territorial boundaries has exacerbated the well-known failures inherent to domestic democratic processes. This process has operated to strengthen the hand of those domestic actors who could benefit from the increased availability of "exit" options from the state; for example, by relocating themselves or their investments, which are options that globalization offers. The threatened "exit" by these actors has increased their "voice" at the expense of the diffuse majority. ${ }^{52}$ The end of the Cold War also meant the end of external threats to national sovereignty and internal threats of popular insurrection, two concerns that had led leaders in some countries to create "a broad social base that identified its economic interests with the success of the regime." ${ }^{53}$ Those leaders felt less need to cater for the interests of diffuse voters when those threats faded and the alternative to market economy has been dealt such a decisive blow.

\footnotetext{
${ }^{52}$ While I don't wish to assume that indigenous minorities had more influence in domestic politics, the increased global demand on their resources has made them more vulnerable to foreign and domestic political markets.

${ }^{53}$ See Jose E. CAmpos, Hilton L. Root, supra note 5 at 28 et seq. (explaining the relative success of certain East Asian economies by efforts to respond to the Communist threat emanating from China through land reform, strong and independent bureaucracy and other welfare promoting measures. In Europe, the Communist threat was certainly one of the main drivers of the rise of the welfare state (see James Petras, The Western Welfare State: Its Rise and Demise and the Soviet Bloc, GLOABLRESEARCH (July 4, 2012), http://www.globalresearch.ca/the-western-welfarestate-its-rise-and-demise-and-the-soviet-bloc/31753.).
} 
A second, related, challenge that globalization poses for the efficacy of high politics within many states springs from the proliferation of small and medium-size states that face increasing competition over access to foreign investment and foreign markets. Divided by political boundaries and high levels of political, social, and economic heterogeneity, these states often find it difficult to forge cooperation instead of competing for the foreign investment or a foreign state's influence. This often makes it relatively easy for a strong economic or political actor-be it a powerful state or a wealthy investor - to practice "divide and rule" strategies against them. ${ }^{54}$ These strategies further erode the capacity of weak sovereigns for collective action and effectively confine them to different "“cells" in a maze of prisoners' dilemmas (or a large, global, prison).

A third challenge to the viability of high politics within national boundaries stems from the lack of congruence between the population of enfranchised voters and the population of parties affected by the voters' decisions. The basic assumption of state democracy - that there is a strong overlap between these two populations - might have been correct in a world of "separate mansions," when territorial boundaries defined not only the persons entitled to vote but also the community that was primarily affected by the choices made. Today, however, this condition is rarely met, and the consequences manifest themselves in two negative ways. First, voters in one country define rights that have spillover effects (e.g., permitting unabated pollution or imposing cap and trade emission regimes that are enforced also on foreigners ${ }^{55}$ beyond their states without the affected stakeholders having the opportunity to participate in the vote or to otherwise influence the decisions that are taken. ${ }^{56}$ Second, foreign actors increasingly employ economic leverage to influence both candidates and domestic public opinion in other states. ${ }^{57}$ This

\footnotetext{
${ }_{55}^{54}$ On the various strategies of "fragmentation" see Benvenisti \& Downs, supra note 37..

55. See Case C-366/10, Air Transport Association of America and others v. Secretary of State for Energy and Climate Change, 2011 E.C.R. I-13755 (regarding the EU emission trading regime which is enforced on foreign airline carriers).

${ }^{56}$ Nadia Urbinati \& Mark E. Warren, The Concept of Representation in Contemporary Democratic Theory, 11 ANN. REV. Pol. SCI. 387, 397 (2008); see also Jean L. Cohen, Constitutionalism Beyond the State: Myth or Necessity? (A Pluralist Approach) 5-6 (RECON Online Working Paper 16, 2010) (discussing the need to reconsider state boundaries when considering sovereignty); Nancy Fraser, Reframing Justice in a Globalizing World, 36 NEW LEFT REV. 69, 71 (2005) (arguing that prior conceptions of the nation-state are insufficient to address modern problems that spill over national borders).

${ }^{57}$ David Schneiderman, Investing in Democracy? Political Process and International Investment Law, 60 U. TORONTO L.J. 909 (2010).
} 
phenomenon may distort the domestic democratic process in the target states and disenfranchise their citizens.

Fourth, the rise of global commons problems (global terrorism, climate change) requires collective responses through regional and international organizations, and this increases the demand for international governance that further reduces the space for national discretion. Consequentially, there is a proliferation of global venues for regulation which are dominated by the executive branches of a small number of powerful states and remain largely inaccessible and quite opaque to most voters, while enabling better-organized and better-funded groups to exploit asymmetric information about the goals and consequences of regulation. Many International organizations have functioned to further disempower diffuse domestic electorates by expanding the executive power of powerful states, especially through "fragmentation": the setting up of multiple regulatory organizations, each with a narrow scope of authority, that prevent smaller and developing states from engaging in the logrolling that is necessary for them to bargain more effectively with the more powerful states. ${ }^{58}$

While these developments render cooperation among diffuse voters across political boundaries through state legislatures and courts almost improbable, they at the same time enfranchise small groups that concentrate their efforts on the executive branches, especially on those of the more powerful states. Faced with the inherent weakness of the legislative and the judicial branches to reach out to their peers in other countries or to second-guess their respective executive in external affairs, as well as the precarious global standing of most states, the promise of domestic checks and balances as a means of disciplining the executive and protecting property rights through high politics has been subjected to serious pressure.

There are plenty of examples not only of the loss of voice and the shrinking effectiveness of domestic checks, but also of the intention to affect these consequences: state and private actors create global arenas for action that will be immune to review by others and secure their unfettered discretion. Examples range from the use of formal international institutions such as the UN Security Council to create a regime of "targeted sanctions" against suspected supporters of global terrorism (which seeks to overcome national constitutions that protect individual rights

\footnotetext{
${ }^{58}$ Benvenisti \& Downs, supra note 37.
} 
and provide for due process), through informal clubs of powerful states that set standards that all others have no choice but to adopt (e.g., anti-money laundering rules set and enforced by the Financial Action Task Force (FATF)), to private actors that set standards (e.g., on food safety, on labor) that are beyond challenge by a single country or even a group of them (and not subject to WTO discipline due to their private nature). ${ }^{59}$ The scandals involving FIFA's World Cup and other sports events ${ }^{60}$ demonstrate how private bodies that exercise essentially public functions and impact the lives and careers of players can remain completely immune to calls for accountability while imposing nonnegotiable demands on member states.

\section{The Rise of Global High Politics?}

(a) Sovereign Reassertion of High Politics

Despite the structural elements that strengthen the hand of "low politics" in our time, we have recently been witnessing an effort to reassert the authority of "high politics" at the state level and thereby influence the global political market. As we saw in the IP norm-setting example, there are still venues of high visibility politics that can be intermittently effective. Motivated by justice, parochialism or greed, a number of national legislatures and courts have succeeded in serving as venues for "high politics" despite the external pressures. ${ }^{61}$ The 2013 judgment of the Supreme Court of India in Novartis $v$. India, ${ }^{62}$ which interpreted narrowly the TRIPS agreement's scope of IP protection, exhibited the potential for offsetting the clout of the big multinationals by using state institutions. ${ }^{63}$ This case "caused a stir, almost in the form of a 'tsunami' among intellectual property practitioners, both nationally and internationally,"64 and

\footnotetext{
${ }^{59}$ Benvenisti, Law of Global Governance, supra note \#, id.

${ }^{60}$ See Eyal Benvenisti, The FIFA Bribery Scandal and the Applicability of the United States' RICO Act Abroad: Possible Implications for Private Global Governance Bodies (2015) available at http://globaltrust.tau.ac.il/the-fifabribery-scandal-and-the-applicability-of-the-united-states-rico-act-abroad-possible-implications-for-private-globalgovernance-bodies/

${ }^{61}$ Eyal Benvenisti, Reclaiming Democracy: The Strategic Uses of Foreign and International Law by National Courts, 102 AM. J. INT'L L. 241 (2008).

${ }^{62}$ Supra note 6.

${ }^{63}$ Gupakumar G. Nair, Andreya Fernandes \& Karthika Nair, Landmark Pharma Patent Jurisprudence in India, 19 J. INTEL. PROP. RTS. 79 (2014).

${ }^{64}$ Id. at 80 .
} 
provided a model for other national courts to emulate. ${ }^{65}$ Indeed, recent evidence suggests that national courts have become aware of the challenges that global low politics poses for their domestic high politics and that they have begun to develop tools to respond to them. In particular, they have exhibited a newfound willingness to intervene in policymaking at the global level and to curb the domestic enforcement of such policies, a trend that holds out the promise of reducing excessive executive discretion and pressure from private companies and of improving domestic accountability. In addition, national courts, primarily of developed democracies, being able to coordinate their judgments with their peers in other countries, have shown some tentative willingness to exploit their considerable independence from their respective executive branches to address review deficits at the international level and to determine which of the often conflicting international legal standards can be applied within their jurisdictions. ${ }^{66}$

There is nothing inherently "good" in the motivation behind such reactions. Ultimately, the motivations for counter-reactions could be anticompetitive, myopic and self-serving. Yet what is inherently good in these reactions is that they generate information that fuels public deliberation. They open the door for public contestation which can be the key to sincere and inclusive public deliberation that would lead to more fair and efficient outcomes.

(b) Counter-Reactions: Contemporary Efforts to Insulate Global Private Markets from High Politics

But the Novartis judgment and other judgments, as well as the European Parliament's rejection of the Anti-Counterfeiting Treaty, ${ }^{67}$ were one of the triggers for the redoubled efforts of "low politics," adding to the motivation of pharmaceutical companies to offer privatized dispute resolution mechanisms as an alternative to national courts to prevent the Novartis precedent from

\footnotetext{
${ }^{65}$ The Supreme Court of Sri Lanka concluded that a bill that would have the precluded compulsory licensing and parallel importing (regarded as important tools to ensure affordable access to pharmaceutical drugs) required a special majority in parliament because it infringed the principle of equality enshrined in the constitution: Case of S.C. Special Determination No.14/2003 available at http://www.elaw.org/system/files/Sri+Lanka+SC+Determination+on+Intellectual+Property+Bill.doc.

${ }^{66}$ On the logic of coordination between national courts that is based on their ability to set common standards and thereby prevent forum shopping by foreign actors, see Benvenisti, supra note 58, at 247-49 (2008) (discussing coordination of national courts in the context of counterterrorism measures, environmental protection, and determination of refugee status).

${ }^{67}$ See infra note 7.
} 
spreading around the developing world. ${ }^{68}$ The ongoing secret negotiations over the so-called "Mega Regional" agreements between the U.S. and its trading partners are set to redefine certain property rights and render them almost immune to the subsequent challenges of high politics.

The negotiations over the "Mega Regional" agreements are being conducted simultaneously: the U.S. is negotiating with the EU over the Transatlantic Trade and Investment Partnership (TTIP), and with eleven other Pacific Rim states over the Trans-Pacific Partnership (TPP). ${ }^{69}$ The TTIP and the TPP are not only about trade. While the negotiating parties are seeking to liberalize trade beyond the WTO framework, they also aim at harmonizing regulation, customs and e-commerce, at setting standards for labor and environmental protection, for protecting foreign investments, government procurement, for medical devices, professional services, pesticides, information and communication technology, pharmaceuticals, textiles, vehicles, sanitary and phytosanitary measures and technical barriers to trade, enhanced protection of intellectual property, limits to state owned enterprises, ${ }^{70}$ and, in general, as U.S. Vice President Joseph Biden candidly said, "to help shape the character of the global economy," ${ }^{, 71}$ or as the U.S. President put it even more starkly when he stated that these "strong, high-standards trade agreements... are vital to ... establishing rules for the global economy that help our businesses grow and hire."72

What are striking about these two efforts are their secrecy and their contents: they epitomize the effort to secure the primacy of low politics by low politics. In other words, the aim is to evade public scrutiny of the process of defining global norms and creating norms and procedures that

\footnotetext{
${ }^{68}$ Amy Kapczynski, Engineered in India - Patent Law 2.0, 369 New EngLAnd J. Med. 497 (2013).

${ }^{69}$ Asia Pacific region states include Australia, Brunei, Canada, Chile, Japan, Malaysia, Mexico, New Zealand, Peru, Singapore, the United States, and Vietnam.

${ }^{70}$ See the EU Textual Proposal - Possible Provisions on State Enterprises and Enterprises Granted Special or Exclusive Rights or Privileges, tabled during the TTIP negotiations ("There is a clear need to understand the behaviour and practices of [state-owned enterprises] in the international trading system, to identify the key concerns and to develop ambitious common rules to discipline the harmful effects of SOEs stemming from undue advantages which would contribute to creating and maintaining a level playing field between public and private market participants."), available at http://trade.ec.europa.eu/doclib/docs/2015/january/tradoc_153030.pdf.

${ }^{71}$ Dan Mullaney \& Ignacio Garcia-Bercero, U.S. and EU Chief Negotiators for the Transatlantic Trade and Investment Partnership (T-TIP), Opening Remarks for the TTIP Round Nine Press Conference (Apr. 24, 2015), available at https://ustr.gov/about-us/policy-offices/press-office/speechestranscripts/2015/april/opening-remarks-usand-eu-chief ;Brett Bickel, Harmonizing Regulations in the Financial Services Industry Through the Transatlantic Trade and Investment Partnership, 29 EMORY INT'L L. REV. 557 (2015).

${ }^{72}$ Barack Obama, President of the United States of America, Statement on Senate Passage of Trade Promotion Authority and Trade Adjustment Assistance (May 22, 2015), available at https://www.whitehouse.gov/the-pressoffice/2015/05/22/statement-president-senate-passage-trade-promotion-authority-and-trade-a.
} 
ensure the control of low politics by insulating decision-making and adjudication of disputes concerning property rights from the influence of high politics. The opaque negotiation processes - key elements of the emerging regime are being publicized through Wikileaks - are intent on undercutting the legislative and judicial branches: both agreements seek to secure for state executives the exclusive control of the interpretation of the agreements, and to relegate dispute resolution between foreign actors and host governments to private arbitrators. ${ }^{73}$

(c) A Budding Counter-Counter-Reaction?

It is not impossible to envision the emergence of a high-politics reaction at the global level, for example by courts in TPP and TTIP countries that may insist on maintaining or recreating democratic safeguards. The recent history of judicial resistance to UN Security Council-led measures against terrorism, ${ }^{74}$ or the reactions in courts of developing countries to economic pressures of foreign actors - dramatically illustrated in the Novartis v. India case - demonstrate the surprising resilience and ingenuity of national bodies. A less plausible but not unthinkable venue of resistance might be grounded in parliamentarian refusal to ratify the agreements or incorporate their provisions into national law. The example shown by the Indian Parliament's narrow interpretation of the TRIPS agreement, which was subsequently endorsed by the Indian Supreme Court in the Novartis judgment, or the example of the European Parliament's rejection of the Anti-Counterfeiting Trade Agreement, may lead the way for other legislatures to impose limits on administrative discretion.

Such reactions could be bolstered by emerging global communities of stakeholders, individuals and activists who rely on the Web to coordinate activities in the global economic markets (grassroots campaigns of boycotting or shaming) and the political markets (influencing lawmakers to regain control over state political markets). The competition will probably continue as ever before.

\footnotetext{
${ }^{73}$ See Eyal Benvenisti, Democracy Captured: The Mega-Regional Agreements and the Future of Global Public Law (GlobalTrust Working Paper Series 08/2015).

${ }^{74}$ Case C-402/05 Yassin Abdullah Kadi v. The Council of the European Union and the Comission of the European Communities, 2008 E.C.R I-06351.
} 


\section{Conclusions}

The aim of this essay was to outline the intricate relations between the economic and the political markets for property as they play out in the global arena. The story is continuously evolving, With globalization, "the state" is no longer the sole, nor even the most important arena where property rights are defined and regulated. But despite the proliferation of arenas, the state has remained and probably will remain a key venue for mediating pressures of domestic and foreign actors, between diffuse and concentrated owners, between high and low politics. What remains to be seen is whether a constellation will emerge by means of which the political competition between the diffuse and the concentrated owners levels the playing field, thereby promoting property rights regimes that are more stable, fair and efficient than what we have now. 